\title{
然 \\ SOBERANIA POPULAR E REFORMA CONSTITUCIONAL: ACERCA DA LEGITIMAÇÃO DEMOCRÁTICA DA MUDANÇA CONSTITUCIONAL
}

\author{
Leonardo Augusto de Andrade Barbosa*
}

Resumo: O artigo discute como os processos de mudança constitucional se relacionam com o princípio da soberania popular. A inadequação das respostas dadas a esse dilema pela teoria constitucional liberal e autoritária provê a oportunidade para, a partir de premissas da teoria discursiva, apontar uma alternativa capaz de conciliar constitucionalismo e democracia. Por fim, as premissas teóricas organizadas ao longo do texto são utilizadas para analisar a proposta de emenda à Constituição n. 157, de 2003, em especial quanto ao papel que a democracia direta exerce (ou pode exercer) na legitimação dos processos de mudança constitucional.

Palavras-chave: Teoria da Constituição. Mudança Constitucional. Democracia. Teoria Discursiva.

\begin{abstract}
This paper discusses how constitutional change connects to the principle of popular sovereignty. The inadequacy of the explanations that both liberal and authoritarian constitutional theories provide to this dilemma delivers the opportunity to point out an alternative capable of reconciling constitutionalism and democracy. In conclusion, the theoretical assumptions organized throughout the paper are brought together in order to analyze the proposal to amend the Constitution n. 157/2003, particularly its implications to the role direct democracy plays (or is able to play) in legitimating constitutional change.
\end{abstract}

Keywords: Constitutional Theory. Constitutional Change. Democracy. Discourse Theory.

\section{Introdução}

As constituições revolucionárias do século XVIII refletem dois ideais que fundam a modernidade: liberdade e igualdade. Liberdade quer dizer, em primeiro lugar, a possibilidade de ruptura com a tradição, de aparecimento do novo na história, para usar a expressão de Hannah Arendt (2001). As constituições manifestam essa pretensão, uma vez que refletem o ato fundacional

\footnotetext{
* Doutor em Direito (UnB). Professor do Mestrado Profissional em Poder Legislativo (Câmara dos Deputados/CEFOR). Analista Legislativo na Câmara dos Deputados desde 2002. Membro do Instituto Brasileiro de História do Direito. Membro do grupo de pesquisa "Percursos, Narrativas e Fragmentos: História do Direito e do Constitucionalismo". Advogado (leonardo.barbosa@ camara.leg.br)
} 
de uma comunidade política que constitui a si própria. Essa comunidade passa, então, a reger-se pelas regras que ela aprova, nos termos de sua Constituição. A igualdade, por sua vez, sugere que a autoridade política que constitui essa comunidade (o "poder constituinte") é o seu povo.

Não é difícil imaginar, diante desse quadro, quão problemático foi, desde o início, conceber a questão da permanência e da mudança constitucional como problema jurídico, por meio da introdução de uma distinção entre poder constituinte e poder reformador (constituído). A pretensão de perfeição e imutabilidade que o jusnaturalismo racionalista infundiu às constituições revolucionárias gerou imediata perplexidade. Na Assembleia Constituinte da França revolucionária, a proposta de Sieyès para atribuir a iniciativa da reforma da constituição ao Jury constitutionnaire foi duramente criticada pelos constituintes. Um deles chegou a sugerir que se aplicasse a pena de morte a qualquer pessoa que propusesse mudanças na Constituição (COLOMBO, 1993, p. 273). Pouco tempo depois, entretanto, o anteprojeto de Constituição girondino, apresentado à Assembleia de 1791, sustentava, com as mesmas palavras de Thomas Jefferson, que um povo tem o direito inalienável de rever, reformar e mudar sua Constituição (ZAGREBELSKY, 2005, p. 42).

As constituições nasceram como obra do povo e nasceram para durar. Mas, enquanto obra do povo, a constituição não seria perpetuamente disponível a esse mesmo povo?

Sieyès sugeria que sim. Ele afirmava que "uma nação não pode nem alienar, e nem se proibir o direito de mudar; e, qualquer que seja sua vontade, ela não pode cercear o direito de mudança assim que o interesse geral o exigir" (SIEYÈS, 2001, p. 50). Ou ainda, nas palavras de Ulrich Preuss, "a vontade da Nação é a fonte pré-constitucional da constituição, e a constituição é a institucionalização da vontade da Nação" (PREUSS, 1994, p. 149).

As constituições modernas viram-se, desde logo, acossadas por demandas contraditórias e igualmente legítimas. Enquanto produto da revolução, a constituição deve ordenar de forma duradoura a sociedade, institucionalizando a mudança e tornando desnecessário o recurso à violência. Enquanto produto da soberania popular, da manifestação de vontade da Nação (ou do povo, na terminologia norte-americana), a constituição é sempre disponível - pode ser alterada ao talante de seu criador, conforme se apresentem as circunstâncias sociais e políticas que o convençam da necessidade de tal medida.

Diante desse dilema antigo e ainda atual, faz algum sentido pensar em "limites" à soberania popular em se tratando de alterações constitucionais? Ou, em termos mais adequados, faz sentido encarar a mudança constitucional como um problema propriamente jurídico? Não estaríamos, ainda pensando com Sieyès, diante de um impossível contrato do povo consigo mesmo (SIEYÈS, 2001, p. 50)? Essa questão é fundamental, até porque foi precisamente com o advento das constituições modernas que a soberania popular se afirmou como princípio básico de organização das sociedades 
políticas. Foi a partir desse momento histórico que conhecemos a ideia de uma comunidade política formada por homens livres e iguais.

Fica a impressão algo paradoxal de que a soberania popular constitui a constituição e é, ao mesmo tempo, constituída por ela.

\section{A Teoria Constitucional Liberal}

A ideia de soberania popular foi costumeiramente contraposta ao constitucionalismo pela tradição liberal. O critério máximo da política para os liberais não é a expressão da vontade majoritária do povo, mas o respeito à Constituição. A Constituição, por sua vez, está imbuída de uma forte tendência contramajoritária, garantida, em primeira linha, pela consagração de direitos fundamentais que funcionam, na perspectiva liberal, como limites pré-políticos à atuação do Estado (HABERMAS, 2002).

É por essa razão que as construções teóricas liberais podem ser um bom ponto de partida para a indagação acerca da utilidade e do sentido de pensar sobre limites à alteração constitucional. Elas oferecem elementos para a reconstrução da tensão entre constitucionalismo e democracia e, a partir daí, para a recolocação do problema sobre o significado da legitimação democrática da mudança constitucional.

Recuperando rapidamente três autores liberais cujas obras se concentram no século XIX Tocqueville, John Stuart Mill e Benjamin Constant - podemos compreender como se constrói o antagonismo entre liberdade e soberania popular. Tocqueville, em "Democracia na América", nos oferece um bom exemplo:

Considero ímpia e detestável a máxima de que, em matéria de governo, a maioria do povo tem o direito de fazer tudo; apesar disso situo na vontade da maioria a origem de todos os poderes. Estarei em contradição comigo mesmo? Existe uma lei geral que foi feita ou, pelo menos, adotada não apenas pela maioria deste ou daquele povo, mas pela maioria de todos os homens. Esta lei é a justiça (TOCQUEVILLE, 1998, p. 294).

O justo é o limite do direito de cada povo. A nação funciona tão-somente como um júri, representando a "sociedade universal", cuja lei perpétua e natural é a justiça. Por fím, o reconhecimento de que a soberania popular só pode estar a serviço da justiça afirma concretamente os limites impostos ao governo da maioria. Tocqueville assevera: "penso, pois, que é sempre necessário pôr em algum lugar um poder social superior a todos os outros, mas creio estar a liberdade em perigo quando esse poder não encontra diante de si nenhum obstáculo que possa reter sua marcha e lhe dar tempo de se moderar" (TOCQUEVILLE, 1998, p. 295).

A preocupação de Stuart Mill é semelhante. Para ele, a autonomia do indivíduo é seriamente ameaçada pelo "direito ilimitado do público de não apenas proibir por lei qualquer coisa 
que pensa ser errada, mas, para prevenir aquilo que pensa ser errado, proibir toda sorte de coisas que admite inocentes" (MILL, 1996, p. 88).

É Benjamin Constant, entretanto, quem melhor articula a necessidade de pensar em limites à soberania popular como questão constitucional. Constant, como sugerimos acima, parte do reconhecimento de que a soberania popular é um princípio da constituição (ele se refere à Constituição francesa de 1814) (CONSTANT, 1989, p. 68). Pensá-la como um poder ilimitado seria um equívoco: para Constant, a ideia de um poder ilimitado está presente exatamente em Hobbes, o autor que traçou com maior precisão os contornos teóricos do absolutismo. Hobbes não hesitou em momento algum na afirmação do caráter ilimitado da soberania do povo, transferida, pela necessidade inafastável da paz social, para as mãos do monarca.

É nesse ponto que reside o cerne da advertência de Constant. Tal como o povo contrata a transferência de seu poder ilimitado para as mãos do monarca absoluto, assim também o fará nos regimes republicanos. Mas não há poder exercido por todos: esse foi o grande equívoco de Rousseau. A soberania que não pode ser alienada, delegada ou representada não pode, ao final, ser exercida. Ao pensar a soberania como poder ilimitado, os defensores da soberania popular miraram o alvo errado. Suas ações dirigiram-se contra aqueles que estavam investidos no poder, não contra o próprio poder ilimitado, o grande mal que se deveria atacar: "É à arma que se tem de atacar, não ao braço que a segura. Há cargas demasiado pesadas para o braço dos homens” (CONSTANT, 1989, p. $63)$.

Assim, a soberania foi conferida à sociedade inteira e, desta, acabou passando à maioria. Da maioria, passou às mãos de alguns homens, às vezes às mãos de um só e, nas palavras de Constant, "causou tanto mal como antigamente".

Nenhuma autoridade sobre a terra deve ter poderes ilimitados: a do povo; a dos homens representantes do povo; a dos reis, qualquer que seja o título com que reinem; ou mesmo a da lei. Sendo a lei, a expressão da vontade do povo, ou do príncipe, segundo a forma de governo, deve circunscrever-se aos mesmos limites que os da autoridade da qual emana. Os cidadãos possuem direitos individuais independentes de toda autoridade social ou política, e qualquer violação pela autoridade é ilegítima (CONSTANT, 1989, p. 68). (destacamos)

Os direitos fundamentais constitucionalmente assegurados devem servir, portanto, como um limite ao exercício do poder político. Há, todavia, um longo caminho entre o reconhecimento dessa premissa e o desenvolvimento dos meios capazes de conferir eficácia jurídica à pretensão que ela expressa. Esses meios surgem apenas com o advento do judicial review e com a afirmação da supremacia constitucional, algo que despertou a atenção de Tocqueville em sua análise sobre os Estados Unidos. Ele estava atento tanto para o fato de que a Constituição Americana era uma constituição rígida quanto para o fato de que os juízes podiam afastar uma lei contrária ou 
contraditória à Constituição. Tocqueville via na forma constitucional uma das mais poderosas barreiras já erguidas contra a tirania das assembleias políticas (TOCQUEVILLE, 1998).

\section{A Teoria Constitucional Autoritária}

O pensamento liberal encontrou no jurista alemão Carl Schmitt um de seus críticos mais ferozes. A crítica de Schmitt é conhecida: haveria uma oposição insuperável entre o individualismo ínsito ao liberalismo e o ideal democrático, político por excelência, construído em torno de identidades baseadas na homogeneidade. O liberalismo nega a democracia e vice-versa. A democracia parlamentar - que representa exatamente a articulação desses dois princípios contraditórios - estaria fadada ao fracasso (MOUFFE, 2000, p. 39). A homogeneidade requerida pela democracia não se contenta com uma igualdade formal. Para Schmitt, ela demanda que os cidadãos comunguem de uma mesma substância.

A obra de Schmitt repousa, assim, na identidade mais ou menos exata entre o povo, o Estado e a constituição. A constituição seria a expressão mais ou menos formalizada de um Estado particular. O Estado, por sua vez, a expressão institucionalizada da coletividade política do povo (DYZENHAUS, 1997, p. 51). Qualquer constituição que mereça esse título deve ser capaz de afirmar a identidade coletiva do povo que a proclama, bem como defini-lo em face de seus inimigos.

Como observa Ulrich Preuss, em sentido político, o povo existe como "singularidade étnica e cultural em seu conjunto, a qual implica sua capacidade de compreender sua alteridade em relação tanto a outros povos como à categoria liberal-universalista da humanidade" (PREUSS, 1994, p. 154).

Essa concepção destoa radicalmente da liberal, que enxerga na formalidade constitucional um elemento essencial. Para Schmitt, a constituição escrita é apenas a expressão do que é fundamental. A teoria constitucional schmittiana distingue com rigor entre a constituição enquanto decisão fundamental de um povo a respeito de sua organização política e as leis constitucionais, sua expressão reduzida a forma, a documento escrito.

O significado dessa concepção para o problema da mudança constitucional e seus limites é evidente. Na correta observação de Dyzenhaus, Schmitt pretendia desqualificar a tese liberal de que a garantia constitucional estava ligada à formalidade e, assim, no caso da Constituição de Weimar, em especial de seu artigo 76, à observância de procedimentos rígidos para a modificação do texto constitucional. Segundo Dyzenhaus (apud, SCHMITT, 1934), as garantias e a proteção que de fato podem ser oferecidas pela constituição são materiais, ou seja, "dependem da natureza da 
constituição em um sentido profundo, existencial” (SCHMITT, 1934, p. 119-120). O próprio Schmitt é enfático ao observar:

Seria um erro - e por certo um erro antidemocrático - tomar por regra absoluta e definitiva da democracia os métodos vigentes no século XIX. A vontade do povo de dar-se uma Constituição somente pode ser demonstrada mediante um fato, e não mediante a observância de um procedimento normativamente regulado (SCHMITT, 1934, p. 95-96) (destacamos).

A constituição schmittiana desenvolve-se como realidade material vivida pelo povo soberano. O poder constituinte permanece como elemento latente, nas palavras de Preuss, “destinado a reemergir manifestamente, atuar como guardião da revolução e preservar o espírito original e selvagem do ato fundacional contra aqueles que, obedecendo a letra da constituição, fraudam o seu espírito" (PREUSS, 1994, p. 156).

\section{Algumas Observações a Partir da Teoria Discursiva do Direito e da Democracia}

Tocqueville, Mill e Constant, por um lado, e Schmitt, por outro, partem de premissas que não podemos mais adotar.

Os liberais tomam os direitos fundamentais como um limite pré-político à atuação do Estado. Nesse sentido, a constituição é introduzida como lei fundamental e "condição necessária e suficiente para o processo democrático" - e não como um resultado dele (HABERMAS, 2003, p. 159). Não há, entretanto, como sustentar uma leitura desse tipo sem recurso às premissas metafísicas do jusnaturalismo. Acatá-las é ignorar que as difíceis questões envolvidas na interpretação dos direitos fundamentais nas sociedades contemporâneas não podem ser resolvidas sem recurso ao debate público, sob pena de resvalarmos para um discurso jurídico elitista e paternalista. O conteúdo e o sentido dos direitos fundamentais (ou seu âmbito de proteção, para usar a linguagem da teoria em voga) não é um dado da realidade.

Schmitt, por sua vez, toma como ponto de partida uma descrição irreal do "povo". A complexificação da sociedade, a diversificação de visões de mundo e o surgimento de modos de vida alternativos tornam impossível que a vida em sociedade dependa apenas de consensos materiais fortes entre cidadãos, pautados pela comunhão de valores compartilhados. Nem mesmo à época da ascensão do nazismo na Alemanha era possível pensar o povo dessa forma ${ }^{1}$.

\footnotetext{
${ }^{1}$ Dyzenhaus, por exemplo, lembra as circunstâncias em que foi aprovado o Enabling Act de março de 1933. Após não ter conseguido uma vitória significativa nas eleições de 5 de março de 1933, Hitler forçou o Parlamento a lhe outorgar poderes constitucionais e legislativos. "O ato foi aprovado numa atmosfera de completa desmoralização, causada pelos atos de terror do Nazismo; apenas os 94 socialistas que foram capazes de chegar ao fórum se opuseram ao ato (...). $\mathrm{O}$ Reichstag estava se reunindo num salão de ópera. Nenhum dos deputados comunistas compareceu ao local, 26 socialistas foram fisicamente impedidos de entrar e o resto dos partidos (...) votou com os nazistas" (DYZENHAUS, 1997, p. 27).
} 
A teoria discursiva do direito e da democracia procura se afastar do individualismo egoísta sem ceder ao organicismo totalitário, estratégias teóricas incapazes de reconciliar autonomia pública e privada. Nem um extremo nem o outro são capazes de explicar como os cidadãos podem se enxergar como autores das normas jurídicas coercitivas, de tal forma que a vigência dessas normas seja, de fato, uma espécie de "autoimposição", e não uma restrição ou limitação heterônoma de suas liberdades individuais. Para explorar a fecundidade do constitucionalismo moderno é preciso reconhecer a incontornável tensão entre direito e democracia, entre direitos fundamentais e soberania popular. Isso requer pensar autonomia pública e privada como cooriginárias.

Não se trata de uma refutação meramente retórica. Habermas compreende a constituição como a concretização histórica de um sistema de direitos. Esse sistema de direitos, por sua vez, deve conter os direitos que os cidadãos acordam atribuir-se reciprocamente para regular sua convivência legitimamente pelos meios do direito positivo (HABERMAS, 1997, p. 158). Regular sua convivência pelos meios do direito positivo significa reconhecer que as normas jurídicas são contingentes e constantemente carentes de fundamentação. Cidadãos (sujeitos livres e iguais) que estão dispostos a ingressar nessa prática devem admitir que será difícil ou mesmo impossível fazêlo sem algumas pré-condições. Por exemplo, não parece plausível que alguém possa se engajar na tarefa de produzir leis se não pode manifestar sua opinião sobre uma questão pública em debate ou se, por exemplo, não pode ter acesso a informações confiáveis sobre a gestão da coisa pública. Da mesma forma, faria muito pouco sentido ingressar em tal empreendimento se seus direitos, enquanto membro dessa comunidade política, pudessem ser cassados sem justificação razoável e sem possibilidade de recurso a um órgão imparcial. E assim por diante.

Nessa linha, os direitos fundamentais não são percebidos como uma limitação externa ao legislador, imposta a partir de fora. São, sim, condições possibilitadoras da prática democrática (HABERMAS, 1997, p. 154). Sem direitos fundamentais, não há como operar a democracia. Que democracia é possível sem liberdade de crença, opinião e informação? Ou sem direito a voto? Ou sem direito a recorrer à justiça no caso de se ver injustamente privado de um direito que reputa seu? Em tal caso, não há, por óbvio, que se falar em democracia.

Mas qual seria, então, o significado da soberania popular? Por que não podemos nos contentar com um "povo schmittiano", enquanto singularidade étnica e cultural, e tampouco com a reflexão republicanista (mais plausível, contudo), que enxerga na política um exercício de autocompreensão ética de uma comunidade autêntica?

Parece-nos que a forma mais plausível de conceber a soberania popular nas sociedades modernas é pensá-la em termos intersubjetivos, o que exclui tanto o paradigma liberal (que opera a partir da agregação de vontades individuais) quanto a alternativa histórica e sociologicamente irreal 
de Schmitt. A teoria discursiva sustenta que o sucesso da política deliberativa depende da institucionalização de procedimentos discursivos e da garantia de condições de comunicação que permitam a formação racional da opinião e da vontade, isto é, uma interconexão entre processos institucionais (formalizados) e a constituição informal da opinião pública. Os direitos fundamentais protegem, em primeira linha, esse processo de formação racional da opinião e da vontade, o qual supõe a interdependência entre autonomia pública e privada dos cidadãos (BARBOSA, 2010). Nessa linha, o lugar simbólico da soberania popular permanece vazio - o povo não é um dado préconstituído. Nas palavras de Friedrich Müller, “nem 'o' homem nem as suas formas de vida comunitária estão definidas de uma vez para sempre. Não são dados supratemporais, dados ‘brutos', hard facts, mas dados modificáveis, in fieri; estão sempre a caminho e por esse motivo se vêem sempre ameaçados de descaminhos" (MÜLLER, 2003, p. 124)².

Essas observações guardam importância para enfrentar, adiante, o recalcitrante debate sobre a flexibilização das regras de reforma constitucional adotadas pela Constituição de 1988.

\section{A Proposta de Emenda Constitucional n. 157, de 2003, e a Flexibilização dos Requisitos Procedimentais de Reforma Constitucional: um Exemplo}

O descontentamento com os procedimentos especiais de reforma constitucional não é uma novidade na história brasileira (BARBOSA, 2012) ou na história constitucional ocidental (ZAGREBELSKY, 2005). Razões muito diferentes, todavia, amparam essa insatisfação.

Sanford Levinson, por exemplo, defende que o procedimento de reforma da Constituição Americana "constitui uma verdadeira jaula de ferro no que se refere à possibilidade de alterar alguns dos mais importantes aspectos (...) [do] sistema político" (LEVINSON, 2006, p. 165). Para ele, por mais que a mudança constitucional possa ser canalizada pela via informal, notadamente pela jurisdição constitucional, essa alternativa é ao mesmo tempo pouco democrática e insuficiente. É pouco democrática porque é pouco transparente: “o grau de importância da mudança é normalmente disfarçado por sua racionalização num incompreensível jargão jurídico, que requer fé excessiva nos juristas e juízes que escrevem as decisões”. E insuficiente, porque, como demonstrou a eleição de George Bush, derrotado no voto popular, mas vitorioso no colégio eleitoral, há certas características centrais da Constituição Americana que dificilmente serão alteradas pela via informal (LEVINSON, 2006, p. 164-165).

\footnotetext{
${ }^{2}$ Cf., ainda, (HABERMAS, 2002, p. 283): "Uma soberania popular, mesmo que se tenha tornado anônima, só se abriga no processo democrático e na implementação jurídica de seus pressupostos comunicacionais, bastante exigentes por sinal, caso tenha por finalidade conferir validação a si mesma enquanto poder gerado por via comunicativa. Sendo mais exato, essa validação provém das interações entre a formação da vontade institucionalizada de maneira jurídico-estatal e as opiniões públicas culturalmente mobilizadas, que de sua parte encontram uma base nas associações de uma sociedade civil igualmente distinta do Estado e da economia".
} 
Levinson está preocupado com a "impermeabilidade" da Constituição à mudança formal e com o déficit democrático que daí decorre. Já os críticos brasileiros, quanto às regras de reforma da Constituição de 1988 (que adota um modelo muito menos severo que o americano), de modo geral, têm outro tipo de preocupação: a "governabilidade". A ideia que rege o discurso revisionista no Brasil é corrigir os excessos de uma Constituição que consagra direitos demais, que regula demais e torna a tarefa do governo complicada demais. Uma Constituição que precisa, na expressão nada delicada de Nelson Jobim, de uma "lipoaspiração" (Audiência pública n. 0100/06, realizada em 8.2.2006, pela Comissão Especial da Proposta de Emenda à Constituição n. 157, de 2003. Disponível em: http://www.camara.gov.br). A crítica de Levinson aos procedimentos de reforma constitucional supõe que a Constituição é um instrumento de afirmação da cidadania, de promoção da autonomia pública. A crítica revisionista, por sua vez, vê na Constituição um mero "instrumento de governo".

O exemplo mais recente pode ser encontrado na defesa de uma nova revisão constitucional, consignada na Proposta de Emenda Constitucional (PEC) n 157, de 2003, que tramitou na Câmara dos Deputados principalmente durante a $52^{\mathrm{a}}$ Legislatura. A PEC encontra-se dormitando na Câmara desde 2006, e não há razão para acreditar que ela um dia será apreciada pelo Plenário. Entretanto, o debate, travado durante sua análise pela Comissão de Constituição e Justiça e de Cidadania (CCJC) e pela Comissão Especial destinada a proferir parecer de mérito sobre a matéria, é revelador e representativo de uma mentalidade forte e ativa no direito constitucional brasileiro.

A proposta original previa que em fevereiro de 2007 a Câmara e o Senado se reuniriam em Assembleia Revisional por um prazo máximo de doze meses, durante o qual deliberariam por maioria absoluta, sempre em dois turnos. Ao final, a revisão seria promulgada em um único ato. $\mathrm{O}$ substitutivo, aprovado em agosto de 2005 pela CCJC da Câmara dos Deputados, de autoria do então deputado Michel Temer, introduziu no texto original da proposta a realização de um referendo, cuja função seria "convalidar" o processo de revisão. A necessidade de convalidação residiria no fato de que a proposta prevê regras menos rígidas do que as constitucionalmente adotadas para a aprovação de emendas à Constituição ${ }^{3}$. Daí, segundo o relator, a inafastável necessidade de "submeter a referendo popular o resultado da revisão constitucional (...) para que o povo, titular do poder constituinte originário, diga se está, ou não, de acordo com o texto revisado" (TEMER, 2005, p. 39.040). Temer cita, em socorro à sua posição, um trecho curioso de uma dissertação de mestrado aprovada pelo programa de Direito do Estado da PUC-SP:

\footnotetext{
${ }^{3}$ Algo que boa parte da doutrina constitucional refuta, sob a rubrica de dupla revisão. Vide, por todos, as considerações de Canotilho: "A tese do duplo processo de revisão, conducente à relatividade dos limites de revisão, parece-nos de afastar. Já atrás, ao tratarmos da tipologia das normas constitucionais, tínhamos alertado para o facto de as normas de revisão serem qualificadas como normas superconstitucionais. Elas atestariam a superioridade do legislador constituinte e perfilam-se como o parâmetro material de controlo especificamente referente às alterações da constituição". (CANOTILHO, 2003, p. 1.067).
} 
A consequência da positivação do princípio da soberania popular é a possibilidade de este determinar qualquer coisa no âmbito jurídico, com efeito vinculante. Em especial, destaca-se a possibilidade de alterar qualquer aspecto material da Constituição, sem que isso represente uma ruptura. Isto ocorre desde que as alterações passem por processos de legitimação ótima, que implicam na participação direta do povo, e de acordo com os mecanismos formais previstos na Carta. A Constituição não limita o povo, só limita o Estado. O povo é soberano (VARGAS, 2003).

A pergunta inevitável é: um referendo nos moldes propostos é capaz de convalidar o vício de procedimento pertinente ao processo de reforma constitucional? O que significa uma resposta afirmativa a essa pergunta?

É preciso reconhecer, em primeiro lugar, que a Constituição não se reduz a uma mera garantia formal, vazia de conteúdo. Já aprendemos (da pior maneira) que a defesa da forma pela forma pode servir para deturpar exatamente aquilo que, com ela, se busca garantir. A PEC n. 157, se colocada em seus devidos termos, está sugerindo a existência de uma espécie de poder constituinte permanente (PAIXÃO, 2006, p. 5), ou, em outras palavras, está negando a própria ideia de Constituição, ao dissolver a distinção entre poder constituinte e poder constituído. Dedica-se, no item anterior, a explicar por quais razões devemos considerar democracia e constitucionalismo (ou soberania popular e direitos humanos) princípios complementares e cooriginários. Pensar autonomia pública sem salvaguardas para a autonomia privada é construir um simulacro de democracia, não mais que isso.

E a "soberania popular" que surgiu nas defesas da PEC 157 inaugurava um poder que não se encontrava simplesmente acima da Constituição, mas um poder que dispensava a Constituição. Não se trata, aqui, de defender um anacrônico fetichismo constitucional, que vê no "excesso" de emendas um grande problema para a legitimidade da Constituição. A Constituição nada diz sobre a quantidade de vezes em que deve ou pode ser emendada. Limita-se a estabelecer os requisitos que devem ser observados para que a reforma seja levada a cabo. O que desrespeita a Constituição não é o suposto número excessivo de emendas ao seu texto, mas expedientes que buscam alterá-la ao sabor de maiorias menos qualificadas do que o exigido pelo poder constituinte originário, sem o ônus de mobilizar o debate público necessário para construir as condições políticas que viabilizem a alteração.

A proposta de revisão implicava, ainda, na possibilidade de que direitos fundamentais fossem veladamente suprimidos ou restringidos, a despeito do teor do artigo $2^{\circ}$, parágrafo único, do texto aprovado na Comissão Especial, segundo o qual a revisão estava vinculada às cláusulas pétreas previstas no art. $60, \S 4^{\circ}$ : “A Revisão Constitucional observará o disposto no art. $60, \S 4^{\circ}$, desta Constituição, sendo-lhe vedado suprimir ou restringir os direitos sociais e os instrumentos de participação popular, previstos no art. 14, incisos I e II, e no art. $61, \S 2^{\circ}$ ”. 
A proposta envolvia riscos aos direitos fundamentais porque, em primeiro lugar, é possível atingi-los sem introduzir qualquer alteração nos dispositivos constitucionais que os enunciam. No momento em que se debatia a PEC n. 157, por exemplo, a prorrogação da chamada DRU (Desvinculação das Receitas da União), que vencia em 2007 estava - e agora, em 2011, novamente, está - em pauta. Este seria um dos temas certos da revisão constitucional. Apesar de "não violar" qualquer direito fundamental diretamente, o impacto da desvinculação sobre as políticas públicas de saúde, por exemplo, é amplamente questionado por vários movimentos sociais e profissionais ligados à área.

Além disso, no intuito de se viabilizar, a proposta incorria em uma contradição performativa tão evidente que lhe retirava qualquer credibilidade. Em uma passagem reveladora, o parecer de Temer apropria-se do pensamento do jurista Celso Bastos para afirmar que

o Poder Constituinte originário afastou do Congresso Nacional (poder constituído) a competência para alterar certas disposições constitucionais. Mas isto não significa que também o fez perante o povo. Até por uma falta de perspectiva eficacial, a Carta não retira do povo a possibilidade de alterá-la ou substituí-la (Conforme transcrito no DIÁRIO DA CÂMARA DOS DEPUTADOS, 16/8/2005, p. 39.042).

É difícil compreender, se essas premissas estão corretas, qual a "perspectiva eficacial" do comando que impunha ao Congresso Revisor o dever de preservar os dispositivos referentes aos direitos fundamentais e à participação popular, pois, ao submeter seus resultados ao crivo do sufrágio direto, a revisão seria chancelada (se aprovada) pelo próprio titular do poder constituinte originário. Em outras palavras, se nenhum limite jurídico subsiste à manifestação contrária do “povo", tampouco subsistiriam aqueles previstos pela PEC n. 157. Qualquer medida adotada pelo Congresso Revisor (por maioria absoluta) que angariasse o apoio popular bastaria para convalidar a supressão de direitos sociais, a redução permanente do quorum para aprovação de emendas constitucionais ou, até mesmo, a revogação dos instrumentos de participação popular direta (pelo próprio "povo", que decidiria, “democraticamente", não mais deles se utilizar...).

Não se trata, aqui, de avaliar a probabilidade política de que esse seria o desenlace daquela tentativa fracassada de revisão constitucional ou, menos ainda, que o será no caso de uma futura tentativa. Trata-se, sim, de perceber que os argumentos levantados por Temer e Roberto Magalhães para legitimar a convocação de uma nova revisão trazem consigo uma insuperável contradição. Prometem uma revisão limitada, mas, para realizá-la, precisam negar exatamente a eficácia da Constituição como limite ao exercício do poder. Os limites sugeridos para o processo revisional pela PEC n. 157, de 2003, não resistem aos mesmos argumentos invocados para legitimá-lo em primeiro lugar. 
Esse quadro aponta para uma espécie de "democracia" sem constitucionalismo, o regime que se torna inexoravelmente a pior das ditaduras, como seguidamente adverte Menelick de Carvalho Netto. Mesmo um defensor radical do princípio majoritário como método justo para solucionar conflitos jurídicos, como Jeremy Waldron, reconhece que a regra da maioria não é necessariamente democrática em todo e qualquer contexto (WALDRON, 2010) ${ }^{4}$. O recurso reiterado de Hitler aos referendos demonstra isso de maneira dramática 5 .

\section{Conclusão}

Por fim, para colocarmos a questão da forma mais direta possível: o princípio da soberania popular, concebido em termos de Estado democrático de direito (que, vale a pena lembrar, é democrático e de direito ao mesmo tempo) autoriza a violação da Constituição a pretexto de alterála em conformidade com os desígnios do "povo"?

$\mathrm{O}$ artigo $2^{\circ}$ do texto constitucional sugere uma resposta. Lá, quando proclamamos que todo o poder emana do povo, proclamamos também que o povo o exerce nos termos desta Constituição, e não em quaisquer termos.

Mas será democrático, então, que uma maioria atual vincule com suas decisões maiorias futuras? Essa é a pergunta que o relator da PEC na Comissão Especial, deputado Roberto Magalhães, se faz, com o apoio de Robert Dahl (MAGALHÃES, 2006, p. 26.831 e ss). Não estaríamos, como sugeria Thomas Jefferson, diante do risco de uma "ditadura dos mortos"? A pergunta do relator pode, é claro, soar deslocada de contexto, considerando que a Constituição Americana data de 1787, e a Constituição Brasileira, de 1988. De toda forma, o raciocínio equipara indevidamente coisas diversas. Defender o respeito a um procedimento cuja finalidade é assegurar a rigidez constitucional e garantir a institucionalização de discursos políticos que submetem a um

\footnotetext{
${ }^{4}$ Para uma análise sobre o controle de constitucionalidade de manifestações colhidas por meio de mecanismos de democracia direta nos Estados Unidos, cf., ainda, o trabalho de Julian Eule (1989-1990, p. 1.503-1.590).

${ }^{5}$ A este respeito, Arnold Zurcher aponta, em 1935, que, entre as instituições políticas que compunham o então recente regime nazista, encontrava-se, "surpreendentemente" o referendo. Zurcher lembra que, em apenas 10 meses, Hitler convocou dois referendos, a mesma quantidade de consultas realizada durante quatorze anos de República de Weimar: “A primeira dica de que o senhor Hitler e seus colegas pretendiam lançar-se nesta aventura pela democracia política veio em 14 de julho de 1933. Exercendo os plenos poderes que lhe foram conferidos pelo Reichstag em março de 1933, o gabinete Alemão decretou que teria autoridade para realizar plebiscitos no futuro, acerca de questões de política nacional e também sobre leis editadas pelo gabinete. A autoridade então arrogada para si pelo gabinete foi usada pela primeira vez em 12 de novembro de 1933, quando consultou o eleitorado sobre sua opinião acerca da abruta retirada do governo Alemão da Conferência de Genebra sobre Desarmamento e sobre sua intenção anunciada de retirar-se da Liga das Nações. Em 19 de agosto de 1934, o gabinete se valeu, pela segunda vez, de sua autoridade auto-conferida para consultar a população quando, em seguida à morte do presidente Von Hindenburg, requisitou que o eleitorado aprovasse a transferência de poderes presidenciais ao Chanceler Hitler, junto com o título oficial de Führer do Reich. Em ambos os casos o veredicto foi esmagadoramente favorável à ação do gabinete, e a satisfação resultante nos círculos oficias assegura que outros referendos serão realizados tão logo alguma política pública os demande" (ZURCHER, 1935). Zurcher estava correto: Hitler ainda convocaria mais dois referendos durante a década de 30, sempre vitorioso nas consultas (LEQUESNE, 2005).
} 
crivo rigoroso as propostas de mudança na Constituição não é o mesmo que bloquear as possibilidades de futuro ou cometer uma violência contra a liberdade dos que virão depois de nós.

A própria experiência americana está aí para desmentir essa tese. A dificuldade envolvida nos processos de emenda à Constituição daquele país não impediu que ela se transformasse profundamente ao longo de seus mais de 200 anos de vigência, ainda que a advertência de Levinson sobre os limites dos processos informais de mudança constitucional deva ser levada a sério. Os "vivos" souberam atualizar o projeto constitucional americano de diversas formas - e esse projeto, antes mesmo de representar uma violência às suas liberdades, conferiu novo sentido às suas "histórias".

Jacques Derrida, ao analisar a Declaração de Independência norte-americana (DERRIDA, 2002, p. 50), usa uma alegoria interessante e paradoxal para descrevê-la: a de um signatário que se inventa com a própria assinatura. David Ingram explica: "a assinatura [de um ato que funda uma Nação] é também um processo não-datado de reapropriação e identificação que ocorre no curso de atos subsequentes, como a aprovação de emendas e leis" (INGRAM, 2006, p. 86). Isto é, a legitimação de um projeto constitucional não se resolve no ato fundacional, mas é adquirida retrospectivamente, na medida em que o texto é renovado e reinterpretado pelas gerações vindouras. É um processo aberto para o futuro.

Nesse sentido, é interessante recuperar a síntese que Zagrebelsky faz a respeito da resposta de Madison à alegação de Jefferson (“o mundo pertence aos vivos”):

(...) se o mundo é por natureza um dom para as gerações vivas, deve pertencer a elas apenas em seu estado natural. Mas, na sociedade civil, as benfeitorias feitas pelos mortos - por exemplo, na luta por independência, cujos benéficos frutos são deixados aos seus filhos - constituem uma dívida que grava as gerações sucessivas, que delas se beneficiam (ZAGREBLESKY, 2005, p. 44-45).

Habermas, seguindo Derrida, parece trilhar um caminho que guarda semelhanças com esse. Para ele, o teor da constituição apenas enuncia o sentido de um projeto destinado à convivência em comunidade política de cidadãos livres e iguais. A constituição que materializa o sistema de direitos é um projeto in fieri, que só se realiza na história. Quando nos referimos à mudança constitucional democrática, mais do que respeito às formalidades constitucionais para a alteração do texto da Constituição, estamos nos referindo também a uma atitude interpretativa que respeita esse projeto. Arendt está correta ao afirmar que a legitimidade de uma constituição reside na capacidade de emendá-la (2001), isto é, de atualizar o projeto original, presente na fundação (ou refundação) de uma comunidade política, e de mantê-lo vivo diante da inevitável imbricação do texto constitucional na história. Por essa razão, a estabilidade do texto constitucional não representa nem ausência de mudança, nem deferência ao poder constituinte originário. Todos que interpretamos a 
constituição (em caráter institucional ou não) temos uma responsabilidade para com esse projeto. Temos que responder à pergunta sobre como as opções que fazemos hoje se relacionam com o aperfeiçoamento e a ampliação do sistema de direitos assentado na constituição, e como esse sistema de direitos nos constitui enquanto comunidade política, enquanto povo politicamente ativo. Isso não se resolve simplesmente contando cabeças, ainda que a democracia direta tenha um papel importante em qualquer estado constitucional. Trata-se de um exercício cotidiano, que deve estar sempre atento para os riscos de retrocesso e para as vicissitudes que necessariamente marcam o desenvolvimento não-linear e, por vezes, surpreendente, das instituições políticas e jurídicas. Requer um esforço para compreender criticamente o nosso passado constitucional e reconstruí-lo de forma coerente, com vistas a um futuro melhor.

\section{Referências}

ARENDT, Hannah. Sobre a revolução. Tradução: I. Morais. Lisboa: Relógio D’Água, 2001.

BARBOSA, Leonardo Augusto de Andrade. Processo Legislativo e Democracia: Parlamento, esfera pública e jurisdição constitucional. Belo Horizonte: Del Rey, 2010.

. História Constitucional Brasileira: Mudança Constitucional, Autoritarismo e Democracia no Brasil Pós-1964. Brasília: Edições Câmara, 2012.

CANOtIlHO, J. J. Gomes. Direito Constitucional e Teoria da Constituição. $7^{\mathrm{a}}$ ed. Coimbra: Almedina, 2003.

COLOMBO, Paolo. Governo e costituzione: la trasformazione del regime politico nelle teorie dell'età rivoluzionaria francese. Milano: Giuffrè, 1993.

CONSTANT, Benjamin. Princípios políticos constitucionais: princípios políticos aplicáveis a todos os governos representativos e particularmente à Constituição atual da França (1814). Rio de Janeiro: Líber Juris, 1989.

DERRIDA, Jacques. Negotiations: interventions and interviews (1971-2001). Tradução: Elizabeth Rottenberg. Stanford: Stanford University Press, 2002.

DYZENHAUS, David. Legality and legitimacy: Carl Schmitt, Hans Kelsen and Herman Heller in Weimar. Oxford: Oxford University Press, 1997.

EULE, Julian N. Judicial review of direct democracy. Yale Law Journal, New Haven, v. 99, p. 1.503-1590, 1989-1990.

HABERMAS, Jürgen. Direito e democracia: entre facticidade e validade. Rio de Janeiro: Tempo Brasileiro, 1997. v. I.

. A inclusão do outro. São Paulo: Loyola, 2002.

Era das transições. Rio de Janeiro: Tempo Brasileiro, 2003.

INGRAM, David. Law: key concepts in philosophy. Londres: Continuum, 2006.

LEQUESNE, Christian. Referenda and European Integration: a misguided procedure? Garnet Policy Brief, n. 1, p. 1-9, nov. 2005. 
LEVINSON, Sanford. Our undemocratic constitution: where the constitution goes wrong (and how We the People can correct it). Oxford: Oxford University Press, 2006.

MAGALHÃES, Roberto. Parecer à Proposta de Emenda à Constituição n ${ }^{\circ} 157$, de 2003. Diário da Câmara dos Deputados, 25.5.2006. p. 26.831 e ss.

MILL, John Stuart. On Liberty. Hertfordshire: Wordsworth, 1996.

MOUFFE, Chantal. The democratic paradox. Londres: Verso, 2000.

MÜLLER, Friedrich. Quem é o povo? A questão fundamental da democracia. $3^{\mathrm{a}}$ ed. São Paulo: Max Limonad, 2003.

PAIXÃO, Cristiano. A constituição subtraída. Observatório da Constituição e da Democracia, n. 1, Brasília, jan. 2006.

PREUSS, Ulrich. Constitutional Powermaking: some deliberations on the relations between the constituent power and the constitution. In: ROSENFELD, M. (ed.) Constitutionalism, identity, difference and legitimacy: theoretical perspectives. Durham: Duke University Press, 1994.

SCHMITT, Carl. Teoría de la Constitución. Madrid: Editorial Revista de Derecho Privado, 1934.

SIEYÈS, Emmanuel J. A constituinte burguesa: qu'est-ce le Tiers État? $4^{\text {a }}$ ed. Rio de Janeiro: Lúmen Juris, 2001.

STOURZH, Gerald. Constitution: changing meanings of the term. In: BALL, Terecen; POCOCK, J. G. A. (Eds.). Conceptual change and the Constitution. Lawrence: University Press of Kansas, 1988.

TEMER, Michel. Parecer à Proposta de Emenda à Constituição nº 157, de 2003. Diário da Câmara dos Deputados, Brasília, 16.8.2005. p. 39.040-39.046.

TOCQUEVILlE, Alexis. Democracia na América: leis e costumes. São Paulo: Martins Fontes, 1998.

WALDRON, Jeremy. A majority in the lifeboat. Boston University Law Review, Boston, v. 90, 2010, p. 1.043-1057.

VARGAS, Alexis. O princípio da soberania popular: seu significado e conteúdo jurídico. Dissertação (Mestrado em Direito do Estado). Faculdade de Direito da Pontifícia Universidade Católica de São Paulo. São Paulo, 2003.

ZAGREBELSKY, Gustavo. Historia y constitución. Madrid: Trotta, 2005.

ZURCHER, Arnold J. The Hitler Referenda. The American Political Science Review, v. 29, n. 1, p. 91-99, fev. 1935.

Artigo recebido em: 20/02/2013

Artigo aceito para publicação em: 04/04/2013 